\title{
CERVANTES, THE HELLENISTIC NOVEL AND THE BYZANTINE NOVEL: THEODORE PRODROMOS AND THE LIBERAL LOVER
}

\author{
Moschos Morfakidis-Filactós
}

DOI: 10.17846/CL.2021.14.2.98-108

\begin{abstract}
MORFAKIDIS FILACTOS, Moschos. Cervantes, the Hellenistic Novel and the Byzantine Novel: Theodore Prodromos and The Liberal Lover. Traditionally it was considered that Cervantes was inspired by the Ethiopics or Theagenes and Chariclea by Heliodorus and Leukippe and Kleitophon by Achilles Tatius when writing his novel, The Liberal Lover, and for this reason this novel was included in the genre which has erroneously been called the "Spanish Byzantine Novel". It is true that this novel by Cervantes largely follows the structure and various characteristics of the novels by both authors from the Hellenistic period, however, it is observed that in both its theme and structure, it is even more similar to the novel Rodanthe and Dosicles by the 12th-century Byzantine philologist and writer, Theodore Prodromos. The question which arises is whether Cervantes could have known about this novel in its original Greek, or in a Latin or Spanish translation now lost. In this case, the life of Cervantes is related to the Renaissance movement in Seville.
\end{abstract}

Keywords: Cervantes' novel, the Hellenistic novel, the Byzantine novel

In 1613, eight years after the publication of Don Quixote (1605), Cervantes edited a collection of twelve prose novels entitled Exemplary Novels, to which the subtitle Most Honest Entertainment was later added, which clarified its moralistic and pedagogical character and its alignment with the dominant morality ${ }^{1}$. This is the first example of a short work in Spanish prose, where the term "novel" is used, and its success established a new orientation in the novel genre in Spain, despite the important influences of the Italian short novel ${ }^{3}$. From then on, the novel would be distanced from the romantic character of the Italian and French novels which were translated at the time.

The collection is considered the most important work by Cervantes after Don Quixote and its success established a new genre that includes themes from real life, which is diametrically opposed to the very extensive chivalric novels, the plots of which went back to ancient times and where the heroes moved between history, mythology and legend (Riley 1962). It is characterized by the use of extensive dialogue and the interpolation of various episodes that do not, however, deprive it of its organic unity (Murillo 1988, 231-250).

1 Nouelas exemplares de Miguel de Ceruantes Saauedra, dirigido a Don Pedro Fernández de Castro [Exemplary Novels of Miguel de Ceruantes Saauedra, addressed to Don Pedro Fernández de Castro], Madrid, Iuan de La Cuesta, 1613. In relation to this collection (Riley 1981, 69-85).

2 The term "novella" of Italian origin, had until then in Spain the meaning of "lie", "mockery", as well as "fact", "event". In the sense of a literary work of a narrative style, it was also conceived as a story (Pabst 1972).

3 Until then, mainly works by Boccaccio, Matteo Bandello and Giraldi Cintio were circulating, which were of an intensely erotic character with descriptions of events that did not fit with the strict morality of Spanish society at that time (Alarcos 1950, 195-235; González de Amezua - Mayo 2001). 
In the second novel in the collection, entitled The Liberal Lover, literary criticism saw the

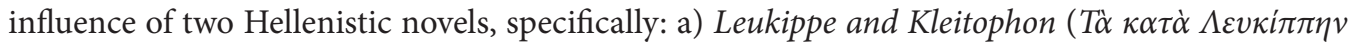

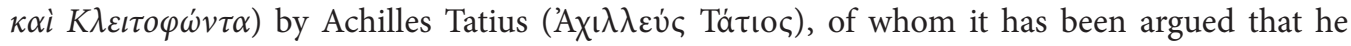
influenced storytelling techniques like no other with his flat, unpretentious, often fresh and vivid style and in the emotional passages (Plepelits 1996, 35); and b) The Ethiopics or Theagenes and

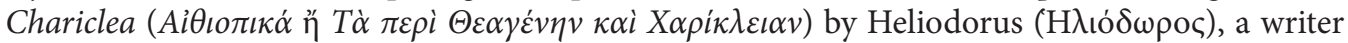
from the 3rd-4th century $\mathrm{AD}^{4}$, who was mistakenly believed to be Byzantine. For that reason, The Liberal Lover was framed within the so-called "Spanish Byzantine Novel". This is the literary trend that developed during the 16th and 17th centuries and which is characterized by the adoption of the characteristics of the Hellenistic novel (González Rovira 1996), a fact we see widely in the Exemplary Novels by Cervantes.

The hypothesis of the influence of Heliodorus and Tatius has been supported by several researchers, mainly by St. Zimic, who considers the adventures of Leukippe and Kleitophon to be the main source of the work, although also with certain influences from Heliodorus (Zimic $1964,363-365,383-385 ; 1989,139-165)$. Others followed him, based mainly on the fact that it is a typical adventure novel, like others by Cervantes, inspired by both Hellenistic novelists ${ }^{6}$. Even though it is true that Cervantes knew both The Ethiopics ${ }^{7}$ and Leukippe and Kleitophon ${ }^{8}$, their plots are very different from The Liberal Lover, but with respect to the narrative technique, he follows the tradition of the Hellenistic novel in several respects (Hagg 1971 \& García Gual 1988):

a) In its structure (Díez Taboada 1979-1980, 87-105):

- It is escape literature focused on love, violence or isolation.

- Starts in media res and has a happy ending.

- The reader is gradually and progressively informed about what has happened until then.

- There are interlocking love stories which come to entangle the story even more, although their role is not as important in the Hellenistic novel.

b) In content:

- Its theme is centred on the love of two young people, who are separated by chance, and their adventures, until their reunion and a happy ending (García Gual 2019, 22-24).

- Their mutual love and fidelity at all costs are the most important elements of the story.

- The purity of love is accentuated even more by the appearance of immoral and degenerate characters, whose sexual appetites endanger the love of the two young people.

- The young protagonists are ordinary characters and not heroes, kings or princes, as in classic literature (Hagg 1983, 90-101).

- The co-protagonism of women (John 1983, 151-208; García Gual 2019, 27-29) gave rise to what has been called "sexual symmetry": equality of lovers in age, social status and emotional capacity;

4 About the author dating cf. Heliodorus, Ethiopics ... 1979, 7-21; E. Crespo Güemes 1996, 129-152.

5 The genre called "Spanish Byzantine Novel” has been studied, among others, by Zimic 1989, 139-165 \& Córdoba 2008, 309-329.

6 Cf. Amezúa y Mayo 1958, 42-66, o the opinions previously expressed about the novel are collected.

7 Heliodorus' Ethiopics had a great influence on French, Italian and Spanish novels. In fact, it was translated into French in 1554 and into Spanish in 1587 by Fernando de Mena who used the Latin version that he also compared with the Greek original.

8 The complete text, in Italian translation, was published by A. Coccio in 1551, and one year later the Spanish version by Alonso Núñez de Reinoso (Venice 1552). 
the males do not play the role of brave saviours and they cry easily, while the women are strongwilled and resourceful (Konstan 1994).

- The desire to endow the story with a certain verisimilitude, placing it in a specific historical setting and with some real characters (Heliodoro 1979, 35-40).

- Dramatic dialogues are interspersed with lyrical passages, reflections, etc.

- Much of the plot takes place at sea, where pirates, storms, shipwrecks and sudden changes of luck violently separate the protagonists, take them to strange and exotic places or lead to their reunion and liberation?.

- Intermediaries bring about the solution to the problem.

- The two lovers use tricks based on lies and deception to achieve their aim (Riley 1962).

Certainly, it has been shown that Cervantes knew of the Ethiopics by Heliodorus while he was writing Don Quixote through the second edition of 1587 (the 1st edition was published in Antwerp in 1554). Leukippe and Kleitophon was known not only from the French translations which had been in circulation since 1551, but also from Italian and Spanish translations ${ }^{10}$. It is also evident that The Liberal Lover contains the characteristics listed above and, consequently, it has correctly been framed in the aforementioned genre of the "Spanish Byzantine novel". However, original elements are also detected that frequently differentiate it from the Hellenistic novel, while in plot development, the coincidences with the two mentioned novels are not so frequent and sometimes they are even minimal (in the case of Heliodorus). In general, in this novel by Cervantes, as in other novels of his, we can observe:

\section{a) From a literary perspective:}

- the circular structure of the action (the starting point and end point is Trapani of Sicily), a fact that differentiates The Liberal Lover from the linear structure of the Ethiopics,

- a strict unity in the action that takes place with few digressions and interspersed stories,

- an apparent realism that responds to the concept of the amazing believable where monstrous beings, prophecies and other things belonging to mirabilia are scarce (Pierce 1953, 134-142),

- regarding time and space, the story of the novel does not take place in a timeless environment but responds to the reality of the author's time and is set in the geographical triangle of Sicily, Tunisia and Cyprus. Even so, it follows the definition of the chronotope that M. Bakhtine has written about as "a foreign world in the time of adventures" (Bakhtine 1978, 239-260),

- the absence of the element of recognising the protagonists after a long and involuntary separation.

b) In content:

- The values of Renaissance humanism, which emphasises the image of a woman who is not the prize for the heroes' exploits and who is in charge of her life (Corral 1981, 397-408).

- The case of Cyprus acquires special drama, as a Christian land that recently (in 1571) fell into the hands of the infidel and therefore, the image of the island is not limited to a simple decoration, but to a poignant geographical space. The text reflects the commotion experienced in the West after the conquest of the island by the Turks as well as the personal life of the author. Let us remember that Cervantes was in Sicily as a soldier, participated in the failed maritime expedition to save Cyprus from the Turkish attack, was discouraged by the news of the Holocaust in Nicosia and Famagusta, followed the process of the creation of the Holy League and participated in the battle of Lepanto, where his left arm was injured. His presence in the Greek seas was followed by

9 For the elements of the adventures Cf. Billault 1991.

10 See the works of Zimic 1967, 166-75; 1974-75, 37-58; 1964. 
other naval expeditions by Don Juan de Austria and, as if that were not enough, in 1575 he became a prisoner at the hands of Turkish-Berber corsairs and spent five years in captivity in Algiers (Garcés 2002). This last adventure will appear repeatedly in his work with fixed motifs: corsairs, galleys, captivity, the payment of ransoms and the conflict of the two worlds in general.

- Contrary to the Ethiopics, there is no divine intervention.

- If there is a certain apologetic attitude towards Christianity in Cervantes' work, it is through the representation of Islam as a superficial and extremely formalistic religion, with its followers plunged into barbarism. It is a fact seen in most literature of the time, where the absolute rejection of the Orient is observed. In this context, the emphasis given to the theme of the repentance of renegades and their return to the true faith is relevant.

- However, a more cultural vision is observed in The Liberal Lover, focused on the clash of two different worlds, which is not always negative, a fact that led to talk of a certain orientalism in Cervantes (Clamurro 1994, 193-200). However, it is clear that an analysis is made of the differences that make the coexistence of these worlds almost impossible and the author's true intention is to present the enormous gap that separates the West from the East in the area of values through the classic motives of love and captivity (Fernández-Morera 2005, 123-166). The best way to signal the superiority of the Christian world is by accentuating differences and developing approaches to identity issues: collective, state, ethnic, religious, individual, sex, etc. (Clamuro 1994, 193-200).

- Regarding the theme of love and the figure of women, it is clear that this is based on the concepts that coexisted in the Renaissance: a) the improved situation of women as individuals and the relative freedom they acquire in the matter of choosing their partner (Alban 1982, 96-157); b) the notion of purity and virginity, which in the Christian world is framed in the person of the Virgin (García Elorrio 1947, 3-15) which dominated worship, art and literature in the Christian West; c) the idea of the institution of marriage in relationships between the sexes, which was the main objective of the work for many people (Pabon 1982, 47-52). The story deals in a dynamic way with the difference between the situation of women in the Christian West and the Islamic East, where they are degraded as purely sexual objects and the cause of all evils: kidnapping, slavery, commercialization, adultery, deception, crime, etc. (Abi-Ayad 1999, 173-184).

Regarding the main reason behind the inspiration for The Liberal Lover, apart from Cervantes's tendency to use the theme of captivity in his works after his traumatic experience of captivity in Algiers (1575 - 1580), it has been noted that it could also be due to:

a) His intention to show that personal sacrifice is the way to reach the liberality (generosity and sacrifice) that ideal love requires.

b) Early Orientalism and a desire to achieve an approach to the almost demonized Turks through descriptions of exotic ceremonies, clothing, customs, etc., or an alleged admiration for the Ottoman judicial system. However, it is noteworthy that this work shows a series of similarities with one of the best-known novels of the period of the so-called Second Byzantine Renaissance or Comnenos' Renaissance (Magdalino 1983, 326-348): that of Rodanthe and Dosicles (T⿳亠丷 $\kappa \alpha \tau \dot{\alpha}$

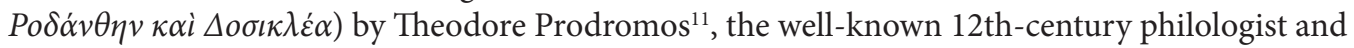
writer. Apart from the standard elements Prodromos' novel shares with the Hellenistic novel, like

11 Il romanzo bizantino del XII secolo. Introduzione, revisione del testo, traduzione e note di Teodoro Prodromo, Niceta Eugeniano, Eustazio Macrembolita e Costantino Manasse, Torino 1994 \& Prodromus, Theodore, Rhodanthe und Dosikles Theodoros Prodromos: eingeleitet, übersetzt und erläutert von Karl Plepelits (translation by Plepelits, Karl), Stuttgart, A. Hiersemann (Bibliothek der griechischen Literatur 42. Abteilung Byzantinistik), 1996; Cf. Martínez Manzano, 2003, 77-92. 
the rest of the novelists of his time (Agapitos-Langwitz Smith 1992), numerous similarities and coincidences are also detected in the plot of both works:

\begin{tabular}{|c|c|}
\hline Rodanthe and Dosicles & The Liberal Lover \\
\hline $\begin{array}{l}\text { In the city of Abydos, the parents of the } \\
\text { beautiful Rodanthe have arranged a wedding } \\
\text { for her; she and her beloved Dosicles flee to } \\
\text { the island of Rhodes. }\end{array}$ & $\begin{array}{l}\text { In the city of Trapani, the beautiful Leonisa } \\
\text { gets engaged to Cornelius; Ricardo, who is } \\
\text { madly in love with her, confronts Cornelius to } \\
\text { avoid the wedding. }\end{array}$ \\
\hline $\begin{array}{l}\text { Rodanthe and Dosicles are captured by } \\
\text { pirates. }\end{array}$ & $\begin{array}{l}\text { Leonisa and Ricardo are captured by Turkish } \\
\text { corsairs. }\end{array}$ \\
\hline $\begin{array}{l}\text { Pirates are impressed by the beauty of } \\
\text { Rodanthe. }\end{array}$ & $\begin{array}{l}\text { One of the chief corsairs is captivated by the } \\
\text { beauty of Leonisa. }\end{array}$ \\
\hline $\begin{array}{l}\text { The satrap Briaxes defeats the pirates, seizes } \\
\text { the two young people and separates them into } \\
\text { different ships. }\end{array}$ & $\begin{array}{l}\text { The leaders of the corsairs separate the two } \\
\text { young people and they embark on separate } \\
\text { ships. }\end{array}$ \\
\hline $\begin{array}{l}\text { Rodanthe's ship sinks, although she is saved } \\
\text { by a merchant ship. }\end{array}$ & $\begin{array}{l}\text { Leonisa's ship sinks and she is rescued by an } \\
\text { Arab merchant ship. }\end{array}$ \\
\hline $\begin{array}{l}\text { Rodanthe is taken to Cyprus where she is sold } \\
\text { as a slave to Craton, Cratandro's father. }\end{array}$ & $\begin{array}{l}\text { A Jew buys Leonisa and takes her to Cyprus } \\
\text { to sell her. Two pashas desire her and to avoid } \\
\text { confrontation, the qadi (who also falls in } \\
\text { love with her) takes her as a gift to the sultan. }\end{array}$ \\
\hline $\begin{array}{l}\text { Dosicles has a companion in captivity, } \\
\text { Cratandro, his compatriot from Abydos. They } \\
\text { bind their fate together. }\end{array}$ & $\begin{array}{l}\text { Ricardo becomes friends with the captive and } \\
\text { convert Mahamut, who is also from Trapani. } \\
\text { They bind their fate together. }\end{array}$ \\
\hline $\begin{array}{l}\text { Cratandro and Dosicles are taken by Craton } \\
\text { from Pisa to Cyprus. }\end{array}$ & $\begin{array}{l}\text { Ricardo arrives in Cyprus as a slave of the } \\
\text { island's new pasha. }\end{array}$ \\
\hline $\begin{array}{l}\text { Reunion of the two young people. Recognition } \\
\text { (at first they do not recognise each other). }\end{array}$ & $\begin{array}{l}\text { Reunion of the two young people. They } \\
\text { immediately recognize each other. }\end{array}$ \\
\hline $\begin{array}{l}\text { Craton's daughter Mirila falls in love with } \\
\text { Dosicles and poisons Rodanthe. Dosicles and } \\
\text { Cratandro save her thanks to a miraculous } \\
\text { plant. }\end{array}$ & $\begin{array}{l}\text { The wife of the qadi, Calima, falls in love with } \\
\text { Ricardo and wants to run away with him. He } \\
\text { pretends that he accepts in order to save the } \\
\text { situation. }\end{array}$ \\
\hline $\begin{array}{l}\text { Thanks to a stroke of luck, Cratandro and } \\
\text { Dosicles escape being sacrificed and regain } \\
\text { their freedom. }\end{array}$ & $\begin{array}{l}\text { Thanks to a stroke of luck, Ricardo and } \\
\text { Mahamut become masters of the situation on } \\
\text { the high seas and regain their freedom. }\end{array}$ \\
\hline The young lovers return to Abydos. & The young lovers return to Trapani. \\
\hline $\begin{array}{l}\text { The parents of the two young people give the- } \\
\text { ir consent for them to marry. }\end{array}$ & $\begin{array}{l}\text { Leonisa's parents give their consent for them } \\
\text { to marry. }\end{array}$ \\
\hline Rodanthe and Dosicles' wedding. & Leonisa and Ricardo's wedding. \\
\hline
\end{tabular}




\begin{tabular}{|c|c|}
\hline \multicolumn{2}{|c|}{ NARRATIVE TECHNIQUES } \\
\hline Rodanthe and Dosicles & The Liberal Lover \\
\hline Written in verse (Byzantine dodeca-syllable). & Written in prose. \\
\hline Love is the central focus of the plot. & Love is the central focus of the plot. \\
\hline $\begin{array}{l}\text { Captivity is the cause of the protagonists' } \\
\text { misfortunes. }\end{array}$ & $\begin{array}{l}\text { Captivity is the cause of the protagonists' } \\
\text { misfortunes. }\end{array}$ \\
\hline Begins in media res. & Begins in media res. \\
\hline Many terrible adventures in strange lands. & Many terrible adventures in strange lands. \\
\hline Reunion $>$ recognition $>$ wedding. & Reunion $>$ recognition $>$ wedding. \\
\hline The narrator agrees with the author. & The narrator agrees with the author. \\
\hline $\begin{array}{l}\text { It is leisure literature, which follows Hellenistic } \\
\text { models. It also has imperial propaganda } \\
\text { purposes (Jeffreys 1974, 143-195). }\end{array}$ & $\begin{array}{l}\text { It is leisure literature, although it also has } \\
\text { propaganda purposes against the Muslim } \\
\text { world. }\end{array}$ \\
\hline $\begin{array}{l}\text { Prodrome writes in classic Greek and addresses } \\
\text { a limited audience that reads historical and } \\
\text { rhetorical works. }\end{array}$ & $\begin{array}{l}\text { Cervantes writes in the spoken language of } \\
\text { his time and consequently addresses a wide } \\
\text { audience. }\end{array}$ \\
\hline $\begin{array}{l}\text { Intense and, at times, abusive use of rhetorical } \\
\text { forms. }\end{array}$ & $\begin{array}{l}\text { Rhetoricism is observed that, at times, slows } \\
\text { down the action. }\end{array}$ \\
\hline Extensive dialogues or monologues. & Extensive dialogues or monologues. \\
\hline $\begin{array}{l}\text { Timelessness of the work which is detached } \\
\text { from historical events. }\end{array}$ & $\begin{array}{l}\text { The work is set in his time and reflects the } \\
\text { confrontation between the Christian world } \\
\text { and the Turkish-Muslim world (16th and } \\
\text { 17th centuries). }\end{array}$ \\
\hline $\begin{array}{l}\text { The pirate attack on Rhodes that H. Hunger } \\
\text { relates to the orthodox Normand king Roger } \\
\text { II against Corfu (1147) (Hunger 1968, 64). }\end{array}$ & $\begin{array}{l}\text { Cervantes narrates aspects of the conquest of } \\
\text { Tripoli by Carlos V (1530). }\end{array}$ \\
\hline $\begin{array}{l}\text { Aspects of Byzantine culture are } \\
\text { shown: imperial protocol, court and } \\
\text { administrative life, details of the embassies. }\end{array}$ & $\begin{array}{l}\text { Aspects of Turkish-Muslim culture are } \\
\text { shown: protocol of the handover of the } \\
\text { city of Nicosia from one pasha to another. } \\
\text { Administrative and judicial life. }\end{array}$ \\
\hline $\begin{array}{l}\text { The work is detached from religious concepts. } \\
\text { The action takes place in a pagan setting in } \\
\text { Greek antiquity, where Christianity does not } \\
\text { appear at all. }\end{array}$ & $\begin{array}{l}\text { The work exalts Christian culture. The action } \\
\text { takes place in a contemporary setting with the } \\
\text { author. }\end{array}$ \\
\hline $\begin{array}{l}\text { The individual is the protagonist and centre } \\
\text { of attention. }\end{array}$ & $\begin{array}{l}\text { The individual is the protagonist and centre } \\
\text { of attention. Emphasizes the role of women. }\end{array}$ \\
\hline
\end{tabular}


Despite the setbacks, the maiden retains her virginity.
Despite the setbacks, the maiden retains her virginity.

There are many similarities since:

a) In both cases there is a love triangle, where the young man in love takes the maiden away from another young man she had a relationship with and a commitment to.

b) The striking return of the two couples to their homelands (Trapani of Sicily and Ábido of the Dardanelles) is noteworthy.

c) The two novels end with the description of the young people's adventures, their parents' consent to marry and the festivities that take place in their cities for the event.

d) The intention to impress with descriptions of exotic ceremonies, clothing, customs, etc. is observed.

All this inevitably leads us to think that it is very probable that Cervantes knew the work of Theodore Prodromos and that he had taken elements of its theme and structure. However, in such a case, the question inevitably arises as to how a Spanish writer of the Renaissance could have access to the text by the Byzantine novelist, poet and philologist. Was a Latin translation available to him? The truth is that in the West, from the sixteenth and especially in the seventeenth century, interest in Greek texts was no longer limited to the classical and Hellenistic period, but is beginning to look tentatively towards works by Byzantine writers. The question is whether Prodromos was among them and whether his texts had reached Italian or Spanish libraries with other manuscripts, during the formation of the large or small collections of Greek codices, among which the collections of the Escorial and the National Library of Spain stand out, in comparison with others with a smaller number of codices, although they are not for that reason of less importance. It is similarly the time when university libraries or humanist private libraries are enriched by the first editions of original works by Byzantine authors. Among them, it would not be impossible for the novel Rodanthe and Dosicles by Theodore Prodromos to attract attention, given its marked classicist character and due to it faithfully following the mould of the Hellenistic novel.

However, the oldest translation of this work into Latin that we know about is from $1625^{12}$, that is, 12 years after the publication of Cervantes' The Liberal Lover. Consequently, the question remains: is it possible that Cervantes had access to Prodromos' text by other means? Could there be another translation of the work that we do not know about today? Is it possible that he had access to any of the manuscripts which came from the West, made it especially in Italy, where he lived for a long time (1569-1580) and that he understood its content with the help of a Greek or Greek connoisseur in his environment? It is impossible to ignore the fact that of the four manuscripts of Prodromes' novel that are preserved today, three are in Italy. Specifically, two (from the 13th and 15th centuries) are in the Vatican Library and one (from the 16th century) is in the Laurentian Library in Florence (Jouanno 2014, 203-234). The hypothesis about his knowledge of Prodromos' novel in the original Greek text or in translation can be reinforced by the fact that texts of Byzantine love novels from the period of the Komnene dynasty, such as Youiv $\kappa_{k \alpha}$ Youlvias by Eustathios Makremvolites, which follow the prototypes of the Hellenistic novel and specifically Achilles Tatius, attracted so much attention that they were translated in the West as

12 Theodori Prodromi philosophi Rhodantes et Dosiclis Amorumlibri IX. Graece et Latine, interprete Gil[berto] Gaulmino Molinensi, Parisiis, 1625. 
early as the 16th century ${ }^{13}$. Furthermore, the fact that many translations of Hellenistic novels were lost, including Heliodorus' Ethiopics, one of the most widely read novels in Western Europe including Spain, should not be ignored (Crespo 1996, 43-55).

Another element that should be taken into account is that from 1587 to 1597, Cervantes lived in the city of Seville as a collector of taxes and merchandise called "Royal Commissioner of Supplies" for cereals and oil, in Andalusia and commissioner of supplies for the Spanish Armada. During this time, and despite the serious problems he had in his work, he became part of the brilliant group of intellectuals and writers who formed what was at that time known as the Renaissance movement in Seville. Indeed, he was lucky to be in this city which in the 16th and 17th centuries was one of the largest metropolises in Europe and one of the most prominent cultural centres, where study of the classics and knowledge of Latin and Greek were booming.

At the time Cervantes was in Seville, the teacher of the Seville school, Juan de Mal Lara (1527 1591), was still living. He was the author of the work Philosophía vulgar and of outstanding poems inspired by Greco-Latin antiquity. Together with his Academy, Mal Lara was the one who laid the foundations of the humanist and Erasmian intellectual court which cultivated and was inspired by the Greco-Latin classics and the poets of the Italian Renaissance, especially Petrarch. His work was responsible for the appearance of artistic and literary circles sponsored by patrons ${ }^{14}$ and of great figures of the Spanish Renaissance ${ }^{15}$. The establishment in Seville of a chair of Greek which promoted the diffusion of Greek arts and where many of the members of the city's intelligentsia studied, laid the foundations for a good knowledge of Greek-Latin antiquity and for a rich editorial activity that included editions of translations of works by Greek and Latin authors (Martínez Carrasco 2020, 14 et seq.), and the cultivation of epic poetry or being inspired by mythological motifs (Lleó Cañal 1979). Most of them were holders of manuscripts and rich bibliographic collections of classical antiquity, among which, in all probability, works by Byzantine authors would have been included ${ }^{16}$. Proof of this is the use of Byzantine works in the original or in translation, such as the Latin translation of the work Proofs of Histories ('A $\pi \circ \delta \varepsilon i \xi \varepsilon \iota \varsigma$

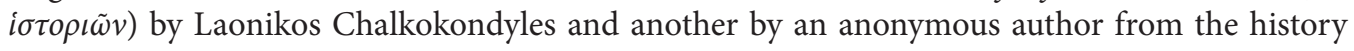
of Scanderberg (Martínez Carrasco 2020, 32). As in the rest of Spain, the interest in Greek arts and everything Greek in general - ancient, Byzantine and post-Byzantine - (Hassiotis 2020, 147208) was surely reinforced by the presence of a considerable Greek community in the city, mainly consisting of merchants and sailors, attracted by the possibilities that the monopoly the port of Seville would have had with the trade of the Spanish colonies of America (Canellas Anoz 2011, 125-172). This presence undoubtedly facilitated the arrival of manuscripts brought from Greek lands, as occurred in other centres where classical studies were developed in Spain (Gil Fernández, 1997). The truth is that many of these books, including translations by ancient Greek, Latin and possibly Byzantine authors, were lost after the decline Seville plunged into after the plague that ravaged the city in 1649 .

Miguel de Cervantes moved and was trained in this environment, he made references to Greek antiquity and mythology on numerous occasions (López Férez 2008, 119-132) and he also studied

13 He was put in jail because of embezzling wheat and being paid his salary twice.

14 Such as the Counts of Gelves, Álvaro de Portugal and Leonor de Milan, and the Marquis of Tarifa, Pedro Afán de Ribera (Cfr. Martínez Carrasco 2020, 12 and ss.), Juan de Arguijo (Escobar 2016 \& Solís de los Santos 2016).

15 Such as Fernando de Herrera, Garcilaso de la Vega, Francisco Pacheco, Baltasar de Alcázar, Diego Hurtado de Mendoza, Juan de la Cueva or Luis Barahona de Soto (Sánchez 1948, 317-343).

16 Bibliography on the Renaissance libraries of Seville and, especially that of its University, includes the work of Solís de los Santos (2017, 63-78). 
the lyrical poetry that he inserted in his novels ${ }^{17}$. Several of his works were written in Seville, while various parts of the city were a source of inspiration for others ${ }^{18}$. Here, he was inspired and wrote a large part of his most famous work Don Quixote, but also some of his Exemplary Novels including The Liberal Lover. In conclusion, we could say that, despite the information we have today, it is not possible to give an answer to questions about the similarity and the circumstances surrounding the writing of The Liberal Lover. However, it can be assumed that Cervantes could have an original or a translation of Rodanthe and Dosicles by Theodore Prodromos to hand and could have made use of its argument and structure which, after all, also followed the canons of the Hellenistic novel.

\section{REFERENCES}

Abi-Ayad, Ahmed. 1999. Las mujeres cervantinas en las obras de cautiverio. In J. Ramón Fernández de Cano y Martín (ed.). In Actas del VIII Coloquio Internacional de la Asociación de Cervantistas. Ayuntamiento de El Toboso. El Toboso. Toledo, 173-184.

Agapitos Panagiotis, A. - Langwitz Smith, Ole. 1992. The Study of Medieval Greek Romance: A Reassessmellf of Recent Work. Copenhagen.

Alarcos, Emilio. 1950. Cervantes y Boccaccio. In Sánchez-Castañer, Francisco (ed.). Homenaje a Cervantes. Valencia. Mediterráneo, t. 2. 195-235.

Alban, Forcione. 1982. Cervantes and the Humanist Vision: A Study of Four "Exemplary Novels. Priceton.

Amezúa y Mayo, Agustín F. 1958. Cervantes, creador de la novela corta española. Madrid.

Bakhtine, Mikhaïl. 1978. Esthétique et théorie du roman. Paris.

Billault, Alain. 1991. La Création romanesque dans la littérature grecque à l'époque impériale, Paris.

Brix, Micheke - Piette, Isabelle. 1994. Sur deux traductions françaises de Théodore Prodrome. In Les Études Classiques 62, 55-58.

Canellas Anoz, Magdalena \& López Gutiérrez, Antonio J. 2011. La presencia de griegos en los fondos documentales del Archivo General de Indias. In $\mathrm{M}^{\mathrm{a}}$ José Osorio (ed.), La presencia del mundo griego en los fondos bibliográficos de España. Perspectivas de investigación. Granada, 125-172.

Murillo, Luis Andrés, 1988. Narrative Structures in the Novelas ejemplares. In Cervantes 8, 231-250.

Conca, Fabrizio. 1994. Il romanzo bizantino del XII secolo. Introduzione, revisione del testo, traduzione e note di Teodoro Prodromo, Niceta Eugeniano, Eustazio Macrembolita e Costantino Manasse. Torino.

Córdoba, Pedro. 2008. Las Novelas ejemplares de Cervantes en el campo de batalla de las interpretaciones: reflexiones metodológicas aplicadas. In Criticón 103-104, 309-329.

Corral, Helia María. 198l. La mujer en las Novelas ejemplares de Miguel de Cervantes Saavedra”. In Manuel Criado de Val (ed.). Cervantes, su obra y su mundo. Actas del I Congreso Internacional sobre Cervantes. Madrid, 397-408.

Cottone. M. T. 1979. La tradizione manoscrina del romanzo di Teodoro Prodromo. Univ. di Padova. 1stituto di Studi Bizantini e Neoellenici. In Miscellanea 2, 9-34.

17 Cf. the Voyage of Parnassus (1614), an allegory of the poetic reality of its time; La Galatea (1585), a mixture of prose and poetry in the pastoral line; famous for its humour and irony sonnet "To the tumulus of Felipe II"; the poems of the "Preliminaries" of Don Quixote or the "Epistle to Mateo Vázquez".

18 The romance Desdén (1592), the sonnet To the tumulus of King Felipe II in Seville (1598), the picaresque genre novels El colloquio de los perros and Rinconete y Cortadillo or the picaresque comedy The Blissful Ruffian. 
Crespo, Emilio. 1996. Introducción a la lectura de Las etiópicas de Heliodoro. In Nova tellus: Anuario del Centro de Estudios Clásicos 14, 129-152.

Escobar, Francisco et alii. 2016. Juan de Arguijo y la Sevilla del Siglo de Oro. El contexto literario. Sevilla.

García Gual, Carlos. 1988. Los orígenes de la novela. Madrid.

García Gual, Carlos. 2019. Historias de amantes peregrinos. Las primeras novelas. Madrid.

Fernández-Morera, Dario. 2005. Cervantes and Islam: A Contemporary Analogy". In A. Robert Lauer - Kurt Reichenberger (ed.). Cervantes y su mundo. t. 3. Kassel, 123-166.

Garcés, María Antonia. 2002. Cervantes in Algiers. A Captive's Tale. Nashville.

García Elorrio, Aurelio. 1947. La devoción mariana de Cervantes. In Estudios 78, 3-15.

Gil Fernández, Luis, 1997. Panorama social del humanismo español (1500 - 1800). Madrid.

González de Amezua y Mayo, Agustín. 2001². Cervantes creador de la novela corta española. Madrid.

González Rovira, Javier. 1996. La novela bizantina de la Edad de Oro. Madrid. Gredos.

Hagg, Tomas. 1971. Narrative Technique in Ancient Greek Romances. Estocolm.

Hagg, Tomas. 1983. The Novel in the Antiquity. Oxford.

Hassiotis, Ioannis, K. 2020. El mundo neogriego en el espejo de los autores del siglo de Oro.

In IEMYR 24, 147-208.

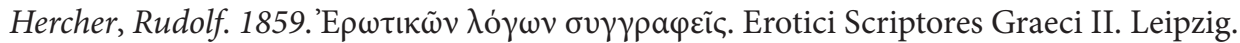

Hunger, Herbert. 1968. Der byzantinische Katz-Mause-Krieg. Theodoros Prodromos, Katomyomachia. Einleitung. Text und Übersetzung. Graz-Viena-Colonia.

Jeffreys, Elisabeth M. 1980. The Komnenian Background to the Romans d'antiquité. In Byzantion 50, 455-486.

John, Renate. 1983. Women in the Ancient Novel, Characterization in the Ancient Novel. In Gareth L. Schmeling (ed.), The Novel in the Ancient World. Leiden - New York, 151-208.

Jouanno, Corinne. 2014. Fortune d'un roman byzantin à l'époque moderne: Étude sur les traductions françaises d'Hysmine et Hysminias de la Renaissance au XVIIIe siècle. In Byzantion 84, 203-234.

Konstan, David. 1994. Sexual Symmetry. Love in the Ancient Novel and Related Genres. Princeton.

Lleó Cañal, Vicente. 1979. Nueva Roma: mitología y Humanismo en el renacimiento sevillano. Sevilla.

López Férez, Juan Antonio. 2008. Personajes históricos griegos o romanos en el Quijote. In Anales Cervantinos 9, 119-132.

Loza Azuaga M. L. - Peñalver Gómez, E. 2016. Juan de Arguijo y la Sevilla del Siglo de Oro. Ordenación documental y bibliográfica y redacción de sus cartelas: Contexto literario. Fuentes mitológicas. In Juan de Arguijo y la Sevilla del Siglo de Oro. Sevilla.

Magdalino, Paul. 1983. Aspects of twelfth-century Byzantine Kaiserkritik. In Speculum 58, 326-348.

Marcovich, Miroslav. 1992. Theodori Prodromi De Rbodanthes et Dosicles amoribus Libri IX. Stuttgart-Leipzig.

Martínez Carrasco, Carlos (ed.). 2020. Fernando de Herrera: Relación de la guerra de Chipre y suceso de la batalla naval de Lepanto Edición, estudio. Granada.

Martínez Manzano, Teresa. 2003. La novela de la época comnena a la luz de la investigación contemporánea: el caso de Rodante y Dosicles. In Erytheia 24, 77-92.

Moreno Jurado, José Antonio. 1996. Teodoro Pródromos, Rodante y Dosicles. Madrid.

Pabon, Thomas A. 1982. Courtship and marriage in El amante liberal: the symbolic quest for selfperfectability, In Hispanofila 76, 47-52. 
Pierce, Frank. 1953. Reality and Realism in the Exemplary Novels". In Bulletin of Hispanic Studies 30, 134-142.

Plepelits, Karl. 1996. Achilles Tatius. In G. Schmeling (ed.). The Novel in the Ancient World. Leiden, 387-416.

Prodromus, Theodore. 1996. Rhodanthe und Dosikles Theodoros Prodromos: eingeleitet. übersetzt und erläutert von Karl Plepelits (traducción de Plepelits, Karl). (Bibliothek der griechischen Literatur 42. Abteilung Byzantinistik). Stuttgart.

Riley, Edward Calverley. 1962. Cervantes' Theory of the Novel. Oxford.

Riley, Edward Calverley. 1981. Cervantes: A Question of Genre». In Medieval and Renaissance Studies on Spain and Portugal on Honour of P. E. Russell. Oxford, 69-85.

Sánchez, Alberto. 1948. Poesía sevillana en la Edad de Oro. Fernando de Herrera, Baltasar del Alcázar, Francisco de Rioja, Juan de Arguijo. Madrid. Castilla, 317-343.

Solís de los Santos, José et alii. (comisarios). 2016. Juan de Arguijo y la Sevilla del Siglo de Oro. El contexto literario. In Juan de Arguijo y la Sevilla del Siglo de Oro. Sevilla, 63-78.

Zimic, Stanislav. 1964. El amante celestino y los amores entrecruzados en algunas obras cervantinas, In Boletín de la Biblioteca de Menéndez Pelayo 40, 361-387.

Zimic, Stanislav. 1967. Alonso Núñez de Reinoso, traductor del Leucipe y Clitofonte, In Symposium 21, 166-75.

Zimic, Stanislav. 1974-75. Leucipe y Clitofonte y Clareo y Florisea en el Persiles de Cervantes, In Anales cervantinos 12-14, 37-58.

Zimic, Stanislav. 1989. Hacia una nueva novela bizantina: El amante liberal”. In Anales Cervantinos 27, 139-165.

Professor Moschos Morfakidis-Filactós

University of Granada

Faculty of Arts

Department of Greek Philology

Centre of Byzantine, Modern Greek and Cypriot Studies

C/Gran Vía 9-2A

18001, Granada

Spain

morfaki@ugr.es 